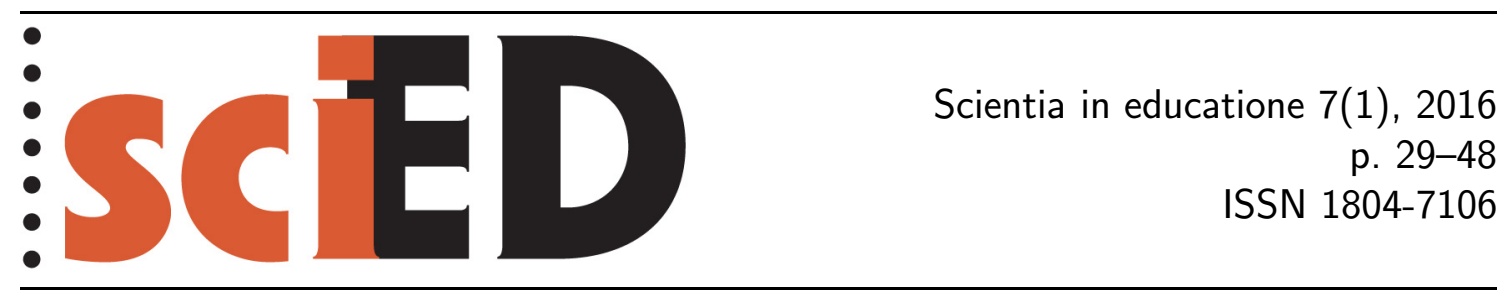

\title{
Chemické úlohy se školními měřicími systémy: motivační orientace žáků v badatelsky orientovaných úlohách
}

\author{
Petr Šmejkal, Marek Skoršepa, \\ Eva Stratilová Urválková, Pavel Teplý
}

\begin{abstract}
Abstrakt
Jedním z klíčových prvků výuky nejen přírodovědných předmětů je motivace žáků. Obecně se má za to, že vhodně volená motivace činí výuku zajímavější a efektivnější, zjednodušuje proces výuky, zapojuje více žáka do sledované problematiky a pomáhá zvýšit retenci získaných poznatků. K tomu, aby výuka mohla maximálně využít motivačního potenciálu vhodně volených prvků (např. vazba na „běžný život“, práce s ICT, ...), je vhodné znát motivační orientace žáků a faktory, které je ovlivňují. V tomto ohledu se př́spěvek zabývá sledováním motivačních orientací žáků při práci se školními měřicími systémy (anglicky MBL nebo probeware) v badatelsky orientovaných úlohách. Dalším motivačním prvkem je propojení úloh na praktický život. Pro studium a zhodnocení motivačních orientací žáci realizovali laboratorní cvičení, před a po laboratorním cvičení vyplnili dotazník založený na ověřených nástrojích pro jejich sledování: (i) Motivated Strategies for Learning Questionnaire (MSLQ) a (ii) Intrinsic Motivation Inventory (IMI). Dotazníky byly statisticky zpracovány - analýzou úrovně reliability (Cronbachovo alfa), analýzou rozptylu (jednoprůchodová ANOVA) a shlukovou analýzou. Výsledky ukázaly, že většina žáků byla již před laboratorní prací dostatečně motivována, jejich motivace se po realizaci cvičení ještě zvýšila. Studované aktivity byly hodnoceny nadprůměrně, zvláště pak ty, které se vztahovaly bezprostředně $\mathrm{k}$ lidskému tělu (účinnost antacid) či medializovaným tématům (plynová chromatografie - methanolová aféra). Analýza rozptylu pak ukázala, že ze sledovatelných faktorů ovlivňující motivační orientace žáků je převážně škola, kterou žák navštěvuje, a potažmo učitel chemie. Naopak, minimálně ovlivňuje motivační orientace pohlaví či realizovaná aktivita. Práce na aktivitách a se školními měřicími systémy žáky ve většině bavila a celkově lze říci, že žáci jsou nakloněni implementaci měřicích systémů do výuky, které tak mají ve výuce přírodních věd nepochybně své místo.
\end{abstract}

Klíčová slova: školní měřicí systémy, badatelsky orientovaná výuka, motivační orientace, vzdělávání v chemii. 


\title{
Chemistry IBSE Activities with Probeware: Pupil's Motivational Orientation
}

\begin{abstract}
The key factor in science education is motivation. Suitable motivation can simplify the educational process, it can involve pupils in studied phenomena, support the knowledge retention, etc. Basic knowledge related to motivation in case of some specific areas of education can help make education more effective and interesting. To employ motivational potential of suitably selected factors (i.e., connection with real life, employment of ICT, ...) in class effectively, it is valuable to know the motivation orientation of pupils as well as the factors which influence it. The article is focused on the study and evaluation of pupils' motivational orientations when performing IBSE (Inquire based science education) activities with implemented MBL (probeware). An important motivation element is connecting the objectives of the activities to "real life" problems. For studying and evaluation of the motivational orientations, pupils filled in two questionnaires (pre- and post-) based on two validated tools: (i) Motivated Strategies for Learning Questionnaire (MSLQ) and (ii) Intrinsic Motivation Inventory (IMI). The questionnaires were statistically evaluated via the reliability test (Cronbach's alpha), the analysis of variance (one-way ANOVA) and cluster analysis. The results showed that the majority of pupils were highly motivated before the course and their motivation increased after the laboratory course. The activities themselves were also evaluated positively, especially those focused on human body (effectivity of antacids) or medialized current affairs (gas chromatography - methanol affair). ANOVA testing showed that the key factor influencing motivational orientations are both the school attended and the chemistry teacher. On the contrary, motivational orientations are not very affected by gender or by the activity performed. Overall, pupils enjoyed the activities and work with MBL and they are in favour of implementing MBL into secondary school laboratories.
\end{abstract}

Key words: probeware, MBL, microcomputer based laboratory, IBSE, inquiry based education, motivational orientations, chemistry education. 


\section{ÚVOD}

Jedním z efektivních nástrojů přírodovědného vzdělávání se jeví školní měřicí (experimentální) systémy, které v posledních letech pomalu nacházejí uplatnění v praxi učitelů chemie. Hovoříme o čidlech ( $\mathrm{pH}$, teplota, tlak, vodivost, spektrofotometr apod.), která jsou pomocí rozhraní připojena $\mathrm{k}$ počítači, notebooku, tabletu, mobilnímu telefonu nebo speciálnímu dataloggeru, jež slouží jako řídicí a zpracovávací/vyhodnocovací jednotka. Tyto systémy mají z hlediska uplatnění v pedagogické praxi jednoduché ovládání a jsou uživatelsky přívětivé, dále musejí být robustní a nenáročné na údržbu. Velkým kladem je okamžité zobrazení sledovaných a měřených dat jak formou numerické hodnoty, tak ve formě grafu, což může zvláště názorně demonstrovat jevy a procesy, které zachycují určitou závislost.

Školní měřicí systémy se v české školní praxi objevují již několik desetiletí. Známé jsou především učitelům fyziky, kteří je mají spojené se systémem ISES vyvinutým Fr. Lustigem (Lustig a kol., 1992). V 90. letech 20. století se jimi v oblasti chemie začal zabývat M. Bílek (nap̌r. Bílek, 1992, 1993, 1997) a v novém tisíciletí pak P. Šmejkal a E. Stratilová Urválková (např. Urválková et al., 2005; Šmejkal \& Stratilová Urválková, 2008, 2012); na Slovensku se využitím měřicích systémů ve výuce chemie zabývá M. Skoršepa (např. Skoršepa, 2001, 2003, 2015). V zahraničí, USA a dalších západních zemích jsou školní experimentální systémy známé již od konce 70. let 20. století, kdy se začala myšlenka zapojení počítačových systémů speciálně vytvořených na podporu přírodovědného vzdělávání rozvíjet (Hood, 1994). Nedlouho poté se experimentální systémy staly tématem pedagogických výzkumů zaměřených na kvalitativní i kvantitativní stránku systémů (Woodard et al., 1981); nepřekvapí, že i zde převládají výzkumy v oblasti fyziky. Výzkumy se zprvu zaměřovaly na technickou stránku věci (např. Lam, 1983; Tinker, 1985; Sneider, 1986), později spíše na pedagogický efekt (Thornton, 1986; Brasell, 1987; Wiserová, 1987). V zahraničí se v souvislosti s využíiáním měřicích systémů v pedagogické praxi stále ještě používá označení (micro)computer-based laboratory (MBL), zavedený R. Tinkerem v 80. letech 20. století (Tinker, 2000), ačkoli tento pojem už není vystihující, zvláště kvůli neaktuálnímu výrazu „mikropočítač“. Nyní se spíše objevuje pojem probeware, zavedený M. Linnovou (dle Tinker, 2000), ke kterému se přiklání i Tinker, pojem však může znamenat jednak samotné hardwarové vybavení nutné k uskutečnění experimentu (významově blíže), ale také počítačem podporovaný experiment. Právě ten je nejčastěji předmětem výzkumů, stejně tak jako byl součástí prezentovaného výzkumu.

Porovnáním klasických laboratorních cvičení a MBL se zabývali např. američtí didaktici fyziky Thorton (1989) a Laws (1991) nebo skupina na Kalifornské univerzitě v Berkeley (Linn, 1988; Nachmias \& Linn, 1987; Stein, 1987). Většina výzkumů ukazuje, že počítačem podporované experimenty např. pomáhají rozvíjet abstraktní myšlení (Hamne \& Bernhard, 2001; Thornton \& Sokoloff, 1990) nebo že žáci prací se školními měřicími systémy zvyšují vědecké kompetence (Tinker, 1996).

Robert Tinker (1984) oceňuje u laboratorního cvičení se školními experimentálními měřicími systémy z pohledu kognitivní psychologie několik výhod: (1) Je experimentálně jednoduché, takže např. sběr dat shrnuje několik kroků, které by bylo nutno v neinstrumentálním pojetí provést ručně. To umožňuje žákům soustředit se více na podstatu experimentu a nezahlcuje pamět a pozornost vedlejšími činnostmi. (2) Rychlá odpověd' měřicího systému a jeho záznam souběžně s průběhem experimentu zpřístupňuje data okamžitě v názorné formě, což urychluje zpětnou vazbu a umožňuje bezprostřední interpretaci, případně vyslovování nových hypotéz. Podle 
Thorntona (1990) tato okamžitá zpětná vazba měřicích přístrojů navíc podporuje skupinové učení, které je pak dalším zdrojem zpětné vazby. Další výhodou je vyšší stupeň přímé zkušenosti (3), která je dána formou, jakou MBL prezentují informace. Vizuální zobrazení dat umožňuje využít nejefektivnější smysl, kterým získává člověk informace - zrak. S tím souvisí také jednoduchost transformace dat (4) při MBL: graf jako soubor vhodně uspořádaných dat vyžaduje při interpretaci aktivní zapojení žáka, který jednotlivé informace musí z grafu extrahovat. Zdokonalování ve čtení grafư se pak promítá i ve vnitřní konverzi a pochopení výsledků experimentu. Využití technologických prostředků podobných těm, které žáci znají ze svého běžného života, pak navíc může u žáků zvyšovat zájem a motivaci pro laboratorní práci (5). Pomineme-li možnost provedení formou demonstračního experimentu, žáci jsou ti, kteří nastavují měření a ovládají přístroj, takže sami ovládají i způsob, jakým se učí. Orientace úloh na žáka (student-centered) a atraktivita dále umožňuje také slabším žákům aktivně se účastnit nejen vlastního měření, ale i následného vyhodnocení dat a diskuse.

Výše rozpoznané výhody tvoří předmět mnoha výzkumů věnujících se relevantnosti a efektivitě počítačem podporovaných experimentů. Sběr dat a jejich současnou vizualizaci „v reálném čase“ ve srovnání s tradičním „neinstrumentálním“ provedením pozitivně hodnotí např. Svec (1999), Nakhlehová (1994) nebo Russell et al. (2003). Celkově lze říci, že ve fyzice byly výzkumy na sledování schopnosti číst grafy velmi oblíbené, zvláště pak výzkumy, ve kterých se použivalo pohybové čidlo. Několikrát se rovněž potvrdilo, že měřicí systémy s okamžitou grafickou odezvou mohou u žáků velmi přispívat ke zvýšení schopností pochopit a správně interpretovat získané grafy (Barton, 1997; Mokros \& Tinker, 1987; Brasell, 1987). Právě bezprostřední grafická odezva je pro žáky nejen zajímavá, ale také přínosná i pro pochopení podstaty sledovaného jevu nebo procesu.

Počítačem podporované experimenty byly zkoumány i z pohledu žáků na jejich implementaci a navzdory většině kladných byly identifikovány i negativní ohlasy. H. Y. Atar (2002) zjistil během výzkumných rozhovorů se žáky, že někteří mají obavy z použivání technologií jako takových, jiným se zase výsledky prezentované touto technologií jeví jako nesrozumitelné. Je pochopitelné, že někteří žáci tedy potř̌ebují větší pomoc učitele. Podobné námitky se vyskytují rovněž v práci Akselové (2005), kdy si někteři žáci stěžovali na složitost a nejasnost práce, na náročnost práce s počítačem nebo měřicím systémem. Nutno dodat, že v tomto výzkumu žáci realizovali badatelsky orientované aktivity. I když se prostřednictvím rozhovorů dovídáme autentické názory žáků, dosud se nám nepodařilo nalézt výzkum, který by se zevrubně věnoval motivaci při realizaci počítačem podporovaných experimentů.

$\mathrm{V}$ rámci tohoto článku bychom proto rádi prezentovali některé výsledky evropského projektu COMBLAB (jde o akronym odvozený ze slov COmpetency Microcomputer-Based LABoratory). Jak napovídá název projektu, The acquisition of science competencies using ICT real time experiments, uvedený projekt je zaměřen na podporu implementace školních měřicích systémů do škol a do výuky, a to zejména na úrovni technické podpory a vývoje a implementací nových, vědecky ověřených, aktivit, $\mathrm{v}$ jejichž rámci jsou školní měřicí systémy využivány. V rámci projektu spolupracují vědečtí pracovníci z šesti evropských univerzit z pěti zemí: (1) Autonomní Univerzita v Barceloně (Španělsko), (2) Univerzita Karlova v Praze (Čská republika), (3) Dolnorakouská univerzita pro vzdělávání učitelů, Vídeň (Rakousko), (4) Univerzita v Barceloně (Španělsko), (5) Helsinská univerzita (Finsko) a (6) Univerzita Mateja Bela v Banské Bystrici (Slovensko). Hlavním cílem projektu bylo vyvinout, zpracovat a implementovat ověřené výukové materiály pro žáky a uči- 
tele, převážně ve formě vhodných aktivit z oblasti přírodních věd, s využitím školních měřicích systémů. Předměty, pro něž byly materiály vyvinuty, jsou fyzika, chemie a biologie. $\mathrm{V}$ rámci tohoto příspěvku bychom rádi prezentovali výsledky našeho výzkumného šetření zaměřeného na motivační orientace ${ }^{1}$ českých žáků s ohledem na práci se školními měřicími systémy v př́padě aktivit orientovaných na chemii.

\section{CÍLE VÝZKUMNÉHO ŠETŘENí}

Jak již bylo řečeno, výzkumným záměrem bylo prozkoumat motivační orientaci žáků při výuce se školními měřícími systémy. Konkrétně nás zajímalo:

1. zda mají jednotlivé nově vytvořené aktivity vliv na motivaci žáků,

2. zda jsou statisticky významné rozdíly v motivaci žáků v závislosti na navštěvované škole, pohlaví či věku žáků nebo na absolvované aktivitě,

3. které aktivity nejvíce zvyšují motivaci žáků,

4. zda lze žáky na základě motivačních orientací rozdělit do určitých skupin, např. více či méně motivovaných žáků ve sledovaných dimenzích (shluková analýza).

\section{PouŽitÁ METODIKA}

K evaluaci motivačních orientací žáků bylo realizováno s každou skupinou žáků vždy jedno laboratorní cvičení, v němž byly využity školní měřicí systémy. Během laboratorního cvičení pak byly využity aktivity vyvinuté v rámci již zmíněného projektu COMBLAB. Tyto aktivity byly založeny na principech badatelsky orientované výuky (BOV) a zároveň zahrnovaly prvky tzv. POE (predict-observeexplain = předpověz-pozoruj-vysvětli) sekvence (White \& Gunstone, 1992). Každá aktivita obsahuje motivační úvod ve formě příběhu, který je nějakým zpơsobem vztažen ke studované či vyučované problematice. Z každého takového úvodu (příběhu) pak vyplývá nějaký problém, a úkolem žáků je tento problém v rámci laboratorního cvičení vyřešit. Posléze jsou žáci v rámci úlohy požádáni, aby navrhli řešení problému a toto řešení experimentálně ověřili. Po návrhu vhodného řešení žáci koncipují experiment, předpovídají výsledky, realizují měření, mění př́ípadná nastavení experimentu (nebo jsou učitelem vedeni ke správnému experimentálnímu uspořádání) a interpretují výsledky. V každém kroku korigují své předpovědi podle skutečně dosažených výsledků. Důležitou součástí úlohy je komunikace výsledků, která má formu dopisu, e-mailu, protokolu apod., dle toho, komu a jak se mají výsledky experimentu prezentovat. Podrobněji jsou koncept i aktivity samotné, včetně didaktické sekvence, prezentovány v práci (Stratilová Urválková et al., 2014), samotné úlohy lze nalézt na webu projektu, v jehož rámci byly vytvořeny. ${ }^{2}$ Pro zjištění motivačních orientací byly žákům v rámci šetření rozdány dva dotazníky založené na nástrojích vyvinutých pro tyto účely - MSLQ (Pintrich et al., 1991) a IMI (Rayn, 1982; McAuley et al., 1989). První dotazník byl žákům rozdán před laboratorním cvičením, druhý po něm. Všechny výsledky prezentované v tomto článku vychází

\footnotetext{
${ }^{1}$ Termín motivační orientace přebíráme z původních zdrojů a chápeme ji jako něco mírně odlišného od motivace, jako vyjádření tendencí vlastních motivací. Dle Higginse (1997) jsou lidské motivační orientace zaměřeny bud' na povzbuzení/zisk či prevenci/předcházení (promotion and prevention focus). $\mathrm{V}$ prvním př́ípadě je proces výběru cílů zaměřen na ideální představy, kterých by chtěl člověk dosáhnout, zatímco u orientace na předcházení hraje roli bezpečí a zodpovědnost. Jinými slovy člověk vybírá cíle s ohledem na potenciální úspěch či neúspěch. O motivační orientaci dále napřr. (Lepper et al., 2005).

${ }^{2}$ Dostupné z www.comblab.eu.
} 
z dat získaných při ověřování chemicky orientovaných aktivit s dostupným vzorkem žáků českých gymnázií a středních škol. Tato studie pak navazuje na obdobné práce realizované v rámci projektu COMBLAB, v jejichž rámci byly implementovány aktivity z biologie a chemie nejen v České republice a na Slovensku (Skoršepa et al., 2014; Stratilová Urválková et al., 2014), ale i v dalších zemích participujících na projektu (Urban-Woldron, 2013).

Šetření prezentovaného v rámci tohoto příspěvku a realizovaného v České republice, zejména na pražských gymnáziích, se zúčastnilo 196 žáků třetích a druhých ročníků čtyřletých oborů (95 chlapců a 92 dívek, 9 neuvedlo pohlaví; průměrný věk $17,8$ let, $S D=0,92)$ z osmi středních škol: tři skupiny žáko̊ byly z běžných tříd (Škola $1(n=16)$, Škola $2(n=17)$ - mimopražská, Škola $3(n=15)$ - soukromá), trri skupiny žáků byly z výběrového chemického semináře (Škola $4(n=45)$, Škola 5 $(n=15)$, Škola $6(n=16))$ a dvě skupiny byli žáci ze středních odborných škol (Škola $7(n=21)$ - obor technické lyceum, Škola $8(n=42)$ - obor chemie). Všichni žáci v šetření realizovali pouze jednu aktivitu, tedy celkový počet evaluací (odevzdaných dotazníků) je shodný s počtem účastníků šetření. Všechna laboratorní cvičení byla realizována na pracovišti autorů aktivit, v laboratořích Katedry učitelství a didaktiky chemie Př́rodovědecké fakulty UK v Praze, vedena byla pracovníky UK s dopomocí učitelů chemie př́íslušných skupin žáků. V rámci výzkumného šetření vyplnili žáci před realizací aktivity motivační vstupní dotazník a po realizaci cvičení a aktivity výstupní dotazník; laboratorní cvičení trvalo, včetně administrace dotazníků, cca 90 min. Dotazníky jsou založeny na zmíněných nástrojích MSLQ a IMI. Vstupní motivační dotazník vyplnili všichni žáci z uvedeného počtu, avšak 9 dotazníků muselo být vyřazeno (žáci nevyplnili vstupní nebo výstupní dotazník). Výstupní motivační dotazník vyplnilo celkem 125 žáků.

Shromážděná data sloužila ke zjištování žáky deklarované motivační orientace před a po realizaci laboratorního cvičení se školními měřicími systémy, dále se zkoumaly spojitosti těchto orientací s faktory, které by mohly př́padně ovlivňovat výsledky, a to zejména pohlaví, realizovaná aktivita, věk a navštěvovaná škola. Data také byla zpracována prostřednictvím shlukové analýzy, která, v závislosti na deklarované motivační orientaci, rozdělila žáky do shluků s obdobnou mírou motivace.

Ke zhodnocení motivačních orientací žáků před a po realizaci aktivity byly využity následující výzkumné nástroje (motivační dotazníky), z nichž bylo pro potřeby našeho výzkumu vybráno vždy 16 položek (tvrzení), každá náležela k jedné ze 4 zvolených škál (vstupni dotazník - Vnitřní cílová orientace, Vnější cílová orientace, Sebeúčinnost v učení se a Vědomí vlastní zodpovědnosti při učení se; výstupní dotaznik: Zájem/potěšení, Uvědomění si svých schopností, Vynaložené úsilí/důležitost a Význam/užitečnost):

1. Motivated Strategies for Learning Questionnaire (MSLQ) (Dotazník motivačních strategii pro učeni se) vyvinutý na přelomu 80. a 90. let minulého století kolektivem autorů vedených Pintrichem (Pintrich et al., 1991) ke zjištování a hodnocení motivačních orientací žáků a jejich využívání různých strategií pro vlastní učení. Tento dotazník byl žákům rozdán před realizací samotného laboratorního cvičení (vstupní dotazník, níže v tabulce zkráceně pre).

2. Intrinsic Motivation Inventory (IMI) (Dotaznik vnitřní motivace) původně vyvinutý pro hodnocení subjektivní zkušenosti vztažené k vnitřní motivaci žáka a vlastní osobní sebe-reflexe (Ryan, 1982; McAuley et al., 1989). Tento dotazník byl žákům administrován po realizaci laboratorního cvičení se zvolenou aktivitou (výstupní dotazník, níže v tabulce zkráceně post). 
Oba dotazníky byly již využity v desítkách studií, jež je potvrzují jako spolehlivé a validní nástroje vhodné $\mathrm{k}$ aplikaci v různých konkrétních podmínkách (Barise, 1998; Cambell, 2001; Monetti, 2002; Niemi et al., 2003; Wolters, 2004; Plant \& Ryan, 1985; Whitehead \& Corbin, 1991; Duda, 1992). Zatím však nikdy nebyly využity ke sledování motivační orientace žáků ve vztahu k přírodovědnému vzdělávání ani ve vztahu k začlenění počítačových měřicích systémů do výuky přírodních věd (Skoršepa, 2015).

Jak bylo řečeno, oba výzkumné nástroje obsahují větší množství různých položek rozdělených do škál, z těchto škál byly v každém výskumném nástroji zvoleny pro naše potřeby 4 škály (tedy 16 položek celkem, z každé škály 4 otázky ve formě deklarativních tvrzení - tabulka 1). Výzkumné nástroje jsou koncipovány jako flexibilní, modulovatelné dle potřeb výzkumu, a proto je není nutné využít v kompletní verzi (Markland \& Hardy, 1997; Pintrich et al., 1991; Rotgans \& Schmidt, 2010). Žáci mohli odpovědět prostřednictvím sedmibodové Likertovy škály (1-7) (Likert, 1932) od polohy „naprostý nesouhlas“ reprezentovaný číslem 1 po „naprostý souhlas“ reprezentovaný číslem 7 . Tento způsob skórování odpovědí byl navržen již v původních pracech referujících o MSLQ a IMI (Pintrich et al., 1991; Ryan, 1982).

Získaná data byla následně vyhodnocena prostřednictvím různých statistických metod. Při komparativních analýzách jsme použili parametrické statistické metody, přičemž jsme vycházeli z vysvětlení Clasona a Dormodyho (1994), kteří popisují rozdíl mezi zpracováváním jednotlivých Likertových položek („Likert-type Items“) a Likertových škál ( „Likert Scale“). Ačkoli mají jednotlivá data získaná měřením na Likertově škále primárně ordinální charakter, při hodnocení jednotlivých škál pracujeme s aritmetickými průměry počítanými ze skóre všech položek patřících $\mathrm{k}$ dané škále, které jsou podle Boonea a Booneové (2012) považované za intervalové proměnné. Právě z tohoto důvodu je při statistickém zpracování takových dat (na rozdíl od dat ordinálního typu) potřebné použít parametrické statistické metody (Boone \& Boone, 2012).

Reliabilita výsledků byla zhodnocena prostřednictvím Cronbachova koeficientu alfa (Cronbach, 1951). Dále byly provedeny korelační analýza a analýza rozptylu (jednoprůchodová) ANOVA pro zhodnocení závislosti získaných dat na zvolených faktorech. Nakonec byla provedena shluková (klastrová) analýza (hierarchická dle Warda (Ward, 1963) pro nalezení vhodných shluků žáků a nehierarchická jako Kprůměry (K-means, Král' et al., 2009) pro vyhledání center jednotlivých nalezených shluků).

Získaná data byla statisticky zpracována pomocí statistického programového balíku IBM SPSS ver. 18 (SPSS Inc., 2009). V některých př́padech vyplněných dotazníků žáci nevyplnili všechny položky dotazníku, popř. tyto položky byly vyplněny nejasně nebo nečitelně. Z těchto důvodi̊ nebyly dané položky do statistického vyhodnocení zahrnuty a počet respondentů ve vyhodnocení neodpovídá celkovému počtu zúčastněných respondentů.

\section{VÝSLEDKY A DISKUSE}

Výsledky prezentované $\mathrm{v}$ tomto příspěvku vycházejí z testování několika chemicky zaměřených aktivit nazvaných: (1) Antacida (aneb zkoumání $\mathrm{pH}$ v žaludku a antacid); (2) Krásný skleník (sledování spekter různých chemických sloučenin a chlorofylu a absorpce světla těmito barvivy); (3) Cervené nebo bílé? (zjištování kyselosti vína, pH titrace); (4) Stanovení chloridů (stanovení chloridů v pitné vodě prostřednictvím konduktometrické titrace), (5) Spektroskopie (kvalitativní a kvantitativní 
analýza barviv) a (6) Tichý zabiják (aneb plynová chromatografie směsi ethanolu a methanolu).

Tabulka 1 ukazuje hodnoty Cronbachova alfa pro všechny námi sledované škály. Tabulka naznačuje, že vnitřní konzistence výsledků je ve většině pozorovaných škálách na požadované úrovni, nebot hodnota Cronbachova alfa překračuje všeobecně přijímané minimum 0,7 prakticky ve všech zvolených škálách. Výjimkou jsou dvě sledované škály vstupního dotazníku), 3 a 4 - „Sebeúčinnost v učení se“ a „Vědomí vlastní zodpovědnosti při učení se", kde je získaná hodnota nižší než požadovaná, byt̉ se hodnotě 0,7 zhruba blíží, nicméně, získané výsledky v těchto škálách je tedy třeba považovat za méně věrohodné.

Tab. 1: Pozorované subškály a koeficienty reliability (Cronbachova alfa) pro motivační orientace žáků

\begin{tabular}{lclc}
\hline Subškála (vstupní dotazník, pre) & $\alpha$ & Subškála (výstupní dotaz., post) & $\alpha$ \\
\hline 1 Vnitřní cílová orientace & 0,73 & 1 Zájem/Potěšení & 0,86 \\
\hline 2 Vnější cílová orientace & 0,74 & 2 Uvědomění si svých schopností & 0,76 \\
\hline 3 Sebeǔčinnost v učení se & 0,65 & 3 Vynaložené úsilí/Důležitost & 0,83 \\
\hline $\begin{array}{l}4 \text { Vědomí vlastní zodpovědnosti } \\
\text { při učení se }\end{array}$ & 0,59 & 4 Význam/Užitečnost & 0,73 \\
\hline
\end{tabular}

Rovněž lze podotknout, že data jsou nejen spolehlivá, což dokazuje uvedený odhad úrovně vnitřní konzistence v rámci sledovaných škál, ale také validní, což bylo dokázáno v rámci jiné studie, kde byly (s analogickými slovenskými daty) psychometrické vlastnosti obou výzkumných nástrojů sledované komplexněji, přičemž kromě reliability byla hodnocena také úroveň konstruktové validity prostřednictvím konfirmační faktorové analýzy (CFA - confirmation factor analysis) (Skoršepa \& Šmejkal, 2015; Skoršepa, 2015).

Korelační analýza naznačuje silné korelace pouze mezi škálami výstupního dotazníku (tabulka 2), což lze zdůvodnit tak, že všechny tyto škály odpovídají vnitřní

Tab. 2: Korelační matice (Pearsonova) pro jednotlivé škály motivačních orientací

\begin{tabular}{|c|c|c|c|c|c|c|c|c|}
\hline & Subškála & Pre1 & Pre2 & Pre3 & Pre4 & Post1 & Post2 & Post3 \\
\hline$\overline{\text { Pre1 }}$ & $\begin{array}{l}\text { Vnitřní cílová } \\
\text { orientace }\end{array}$ & 1,00 & & & & & & \\
\hline$\overline{\text { Pre2 }}$ & $\begin{array}{l}\text { Vnější cílová } \\
\text { orientace }\end{array}$ & $-0,07$ & 1,00 & & & & & \\
\hline$\overline{\text { Pre3 }}$ & $\begin{array}{l}\text { Sebeúčinnost } \\
\text { v učení se }\end{array}$ & $0,46^{* *}$ & $0,21^{* *}$ & 1,00 & & & & \\
\hline$\overline{\text { Pre4 }}$ & $\begin{array}{l}\text { Vědomí vlastní } \\
\text { zodpovědnosti při } \\
\text { učení }\end{array}$ & $0,33^{* *}$ & 0,05 & $0,25^{* *}$ & $\overline{1,00}$ & & & \\
\hline$\overline{\text { Post1 }}$ & Zájem/potěšení & 0,17 & 0,07 & $0,19 *$ & 0,09 & 1,00 & & \\
\hline$\overline{\text { Post2 }}$ & $\begin{array}{l}\text { Uvědomění si } \\
\text { svých schopností }\end{array}$ & $0,25^{* *}$ & 0,17 & $0,29^{* *}$ & 0,09 & $0,74^{* *}$ & 1,00 & \\
\hline$\overline{\text { Post3 }}$ & $\begin{array}{l}\text { Vynaložené } \\
\text { úsilí/důležitost }\end{array}$ & $0,30^{* *}$ & $0,20^{*}$ & $0,34^{* *}$ & $0,29 * *$ & $0,54^{* *}$ & $0,55^{* *}$ & 1,00 \\
\hline$\overline{\text { Post4 }}$ & Význam/užitečnost & $0,34^{* *}$ & 0,03 & $0,27^{* *}$ & $0,28^{* *}$ & $0,67^{* *}$ & $0,56^{* *}$ & $0,57^{* *}$ \\
\hline
\end{tabular}


motivaci a seberegulaci v učení se. Určité slabší korelace lze ve vstupním dotazníku pozorovat mezi položkami škál „vnitřní cílová motivace“ a „sebeúčinnost v učení se" a všemi položkami výstupního dotazníku, což taktéž koresponduje s tím, že tyto subškály se týkají vnitřní motivace sebeúčinnosti v učení se a položky výstupního dotazníku se týkají vnitřní motivace a seberegulaci v učení se. Naopak, položky vstupního dotazníku prakticky nekorelují, což odpovídá tomu, že každá subškála se týká jiného typu motivační orientace (až na položky 1 a 3 vstupního dotazníku). Uvedené dále potvrzuje velmi přijatelnou vnitřní integritu získaných dat. Z dalších důsledků uvedených korelací v tabulce 2 (např. vysoká korelace Post 1 s Post 2 a 3 tyto významné korelace jsou vyznačeny šedým podbarvením) lze např. zmínit, že pokud žáky úloha (laboratorní práce) bavila, uvědomovali si zároveň její význam a rádi věnovali úsilí pro splnění kladených úkoli̊. Z toho nicméně vyplývá a zároveň se potvrzuje, že motivační aspekt je třeba při koncepci úlohy mít na mysli a do úloh tyto prvky důsledně vkládat.

Dále byl sledován vliv vybraných faktorů (pohlaví, věk, navštěvovaná škola, absolvovaná aktivita) na motivační orientace žáků, konkrétně metodou analýzy rozptylu (ANOVA - jednoprůchodová). Výsledky sumarizuje tabulka 3.

Tab. 3: Statistická významnost čtyř sledovaných faktorů prostřednictvím analýzy rozptylu (jednoprůchodová ANOVA) (vstupní a výstupní dotazník) - Rozdíly mezi skupinami jsou považovány za signifikantní na hladině významnosti 0,05 , statisticky významný rozdíl je zvýrazněn. V tabulce jsou uvedeny hodnoty významnosti $(p)$

\begin{tabular}{llcccc}
\hline & Škála & Pohlaví & Škola & Věk & Aktivita \\
\hline Pre1 & Vnitřní cílová orientace & 0,986 & 0,016 & 0,231 & 0,110 \\
\hline Pre2 & Vnější cílová orientace & 0,335 & 0,224 & 0,412 & 0,005 \\
\hline Pre3 & Sebeúčinnost v učení se & 0,419 & 0,222 & 0,165 & 0,703 \\
\hline Pre4 & Vědomí vlastní zodpovědnosti při učení se & 0,545 & 0,044 & 0,172 & 0,129 \\
\hline Post1 & Zájem/potěšení & 0,552 & 0,024 & 0,236 & 0,517 \\
\hline Post2 & Uvědomění si svých schopností & 0,719 & 0,095 & 0,494 & 0,985 \\
\hline Post3 & Vynaložené úsilí/důležitost & 0,040 & 0,001 & 0,780 & 0,096 \\
\hline Post4 & Význam/užitečnost & 0,246 & 0,055 & 0,454 & 0,468 \\
\hline
\end{tabular}

Závislost motivační orientace na pohlaví se při studiu motivačních orientací žáků v případě uvedených úloh nepotvrdila, což naznačuje, že práci se školními měřicími přístroji nepreferují více chlapci, u nichž lze předpokládat technickou preferenci spíše než u děvčat. Jediný statisticky významný rozdíl v př́ípadě pohlaví byl vysledován v př́padě škály „vynaložené úsilí/důležitost", kdy dívky byly ochotny pro splnění cílů aktivity vynaložit větší úsilí a přikládali jí větší důležitost než chlapci $\left(F(1,122)=4,292, p=0,040 ; M_{\text {chlapci }}=4,79, S D=1,28, M_{\text {dívky }}=5,23\right.$, $S D=1,03)$. Podobně jako u pohlaví nebyla prakticky žádná závislost motivační orientace žáků vysledována ani $\mathrm{v}$ případě věku (popř. navštěvovaného ročníku), nicméně, věkové rozmezí ve sledované skupině žáků bylo poměrně malé na to, aby se uvedený faktor významněji projevil. Překvapivě se také neprojevila žádná závislost na realizované aktivitě a dle všeho žáci všechny aktivity z pohledu jejich motivace vnímali prakticky totožně a většina hodnocení ležela nad středovou hodnotou 4. To naznačuje, že vytvořené aktivity jsou z hlediska motivace, a dovolujeme si tvrdit, že i po odborné stránce, velmi dobře využitelné pro výuku na SS̆ v badatelsky orientovaných hodinách. Za zajímavé lze považovat, že žáci, kteří se cvičení účastnili, nevnímali např. spektroskopická měření, i přes jistou obtížnost, 
za méně motivující než např. měření $\mathrm{pH}$ a potenciometrickou titraci vína. Z diskuzí se žáky lze vyvodit, že jejich motivace $\mathrm{k}$ realizaci úlohy vyplývala zejména z úvodního příběhu, který byl hlavním motivačním prvkem, samotný obsah úlohy byl prostředkem ke splnění cúlů, nehrál tedy s ohledem na motivaci až takový vliv. To se projevuje ve většině položek vstupního a výstupního dotazníku, u výstupního dotazníku lze daný výsledek vysvětlit také tím, že všechny úlohy byly pro žáky obdobně náročné. Jedinou výjimkou, kde se projevila závislost na aktivitě (úloze), byla škála vstupního dotazníku „vnější cílová orientace“ $(F(5,159)=3,499$, $p=0,005 ; M_{\text {Antacida }}=5,28, S D=1,18, M_{\text {Skleník }}=3,87, S D=1,21, M$ Víno $=3,98$, $S D=1,44, M_{\text {Chloridy }}=3,99, S D=1,30, M_{G C}=4,71, S D=1,15, M_{\text {Spektro }}=3,62$, $S D=1,43)$, kde se ukázalo, že z hlediska vnější motivace žáci nejvíce preferovali aktivitu s antacidy (ovlivňování $\mathrm{pH}$ v žaludku pomocí antacid), dále plynovou chromatografii, a již méně ostatní úlohy (obr. 1, vyznačený obdélník).

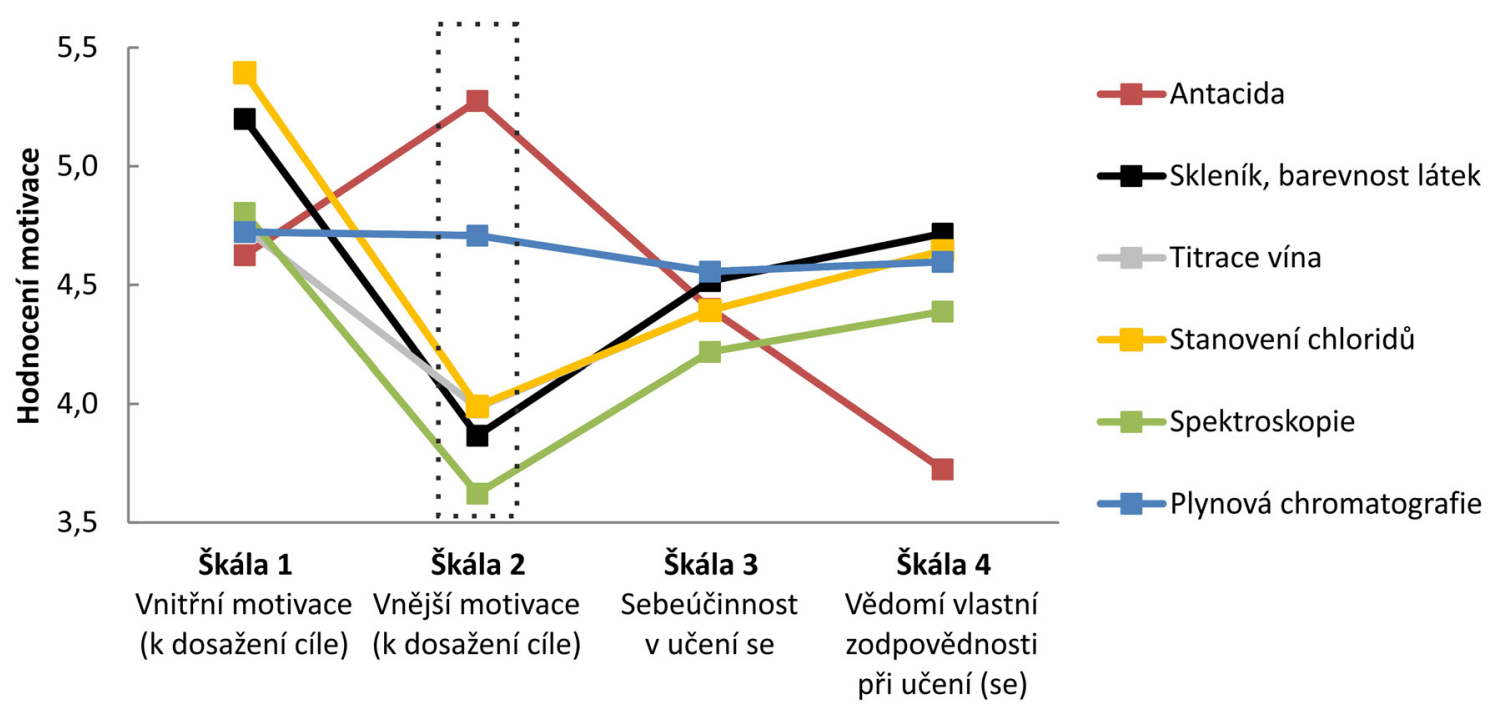

Obr. 1: Motivační orientace žáků - vstupní dotazník (Pre) - vliv realizované aktivity (střední hodnoty)

Dané zjištění lze interpretovat tak, že úlohy jsou do značné míry zaměřeny na aplikace v běžném životě a někdy i medializované (např. tzv. methanolová aféra v př́padě úlohy zaměřené na plynovou chromatografii (GC)), úloha s antacidy se zase dotýká zdraví, což jsou témata, která žáky obvykle motivují více. To bylo pozorováno i ve výsledcích prezentovaných $\mathrm{v}$ našem předchozím článku zaměřeném na obdobně koncipované aktivity z biologie (Stratilová Urválková a kol., 2014). Nepřekvapivá je pak skutečnost, že motivační orientace žáků před realizací aktivity (vstupní dotazník) prakticky nezávisí na realizované aktivitě, nebot žáci povětšinou před realizací aktivity nevěděli, co budou dělat a kromě názvu s úlohou (dle zkušenosti z realizace) seznámeni moc nebyli. Ve výsledku pak jediným faktorem, u nějž analýza ukázala významnější vliv na motivační orientace žáků, je navštěvovaná škola. V tomto prŕpadě lze vypozorovat rozdíly mezi jednotlivými skupinami (školami) v několika položkách vstupního dotazníku (viz vyznačené rámečky v obr. 2) - ve vnitřní cílové motivaci (Pre1) $\left(F(7,179)=2,554, p=0,016 ; M_{\text {škola1 }}=4,72, S D=0,92\right.$, $M_{\text {škola2 }}=5,24, S D=1,06, M_{\text {škola3 }}=5,08, S D=0,97, M_{\text {škola } 4}=5,12, S D=0,88$, $M_{\text {škola } 5}=5,15, S D=0,82, M_{\text {škola } 6}=5,38, S D=0,72, M_{\text {škola } 7}=4,38, S D=1,42$, $\left.M_{\text {škola8 }}=4,60, S D=1,18\right)$ a u "Uvědomění vlastní zodpovědnosti při učení se" (Pre4) $\left(F(7,179)=2,113, p=0,044 ; M_{\text {škola1 }}=4,61, S D=0,72, M_{\text {škola2 }}=4,74\right.$, $S D=0,78, M_{\text {škola3 }}=4,98, S D=0,85, M_{\text {škola } 4}=4,69, S D=1,00, M_{\text {škola } 5}=4,83$, 


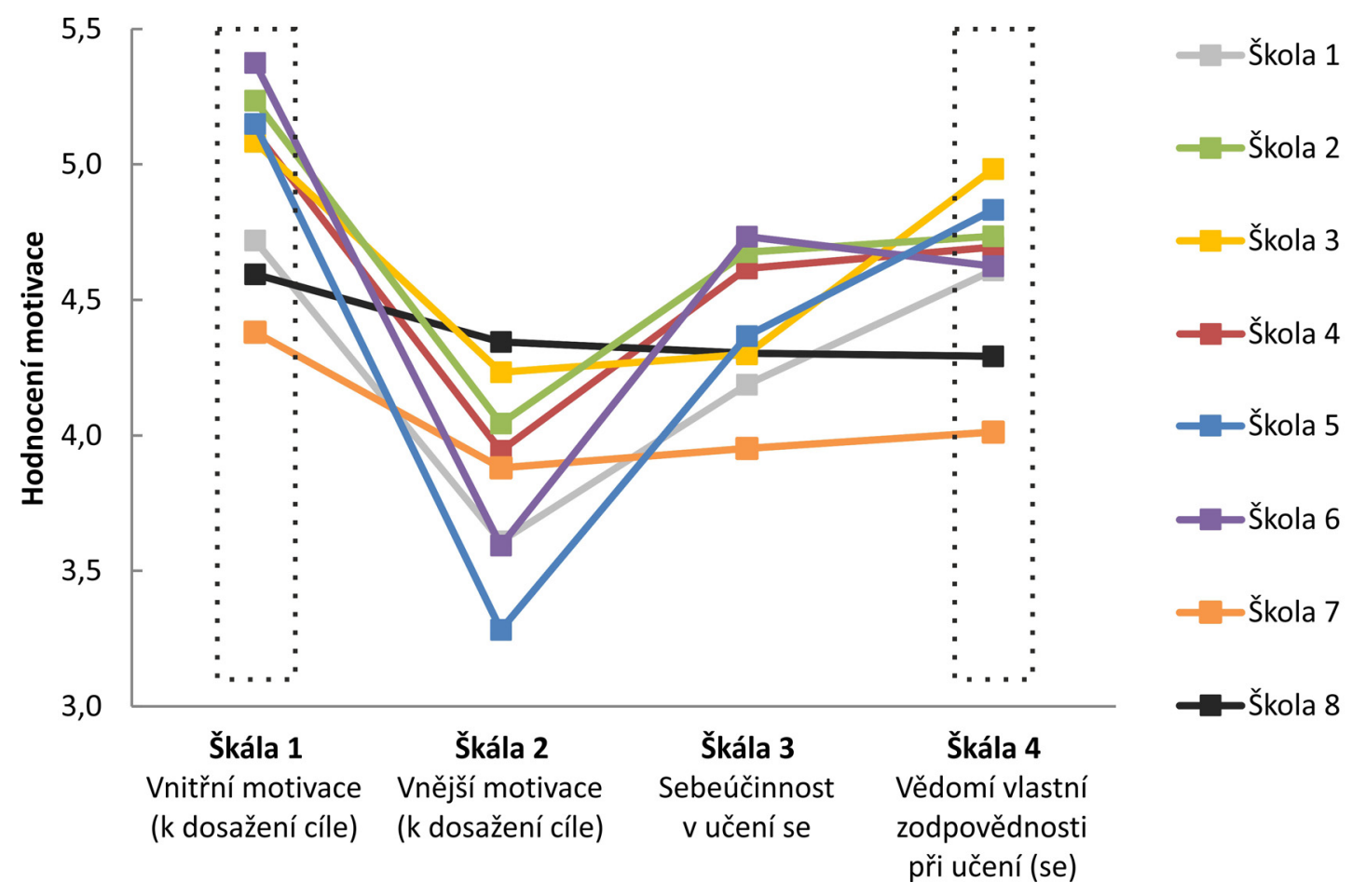

Obr. 2: Motivační orientace žáků - vstupní dotazník (Pre) - vliv navštěvované školy (střední hodnoty)

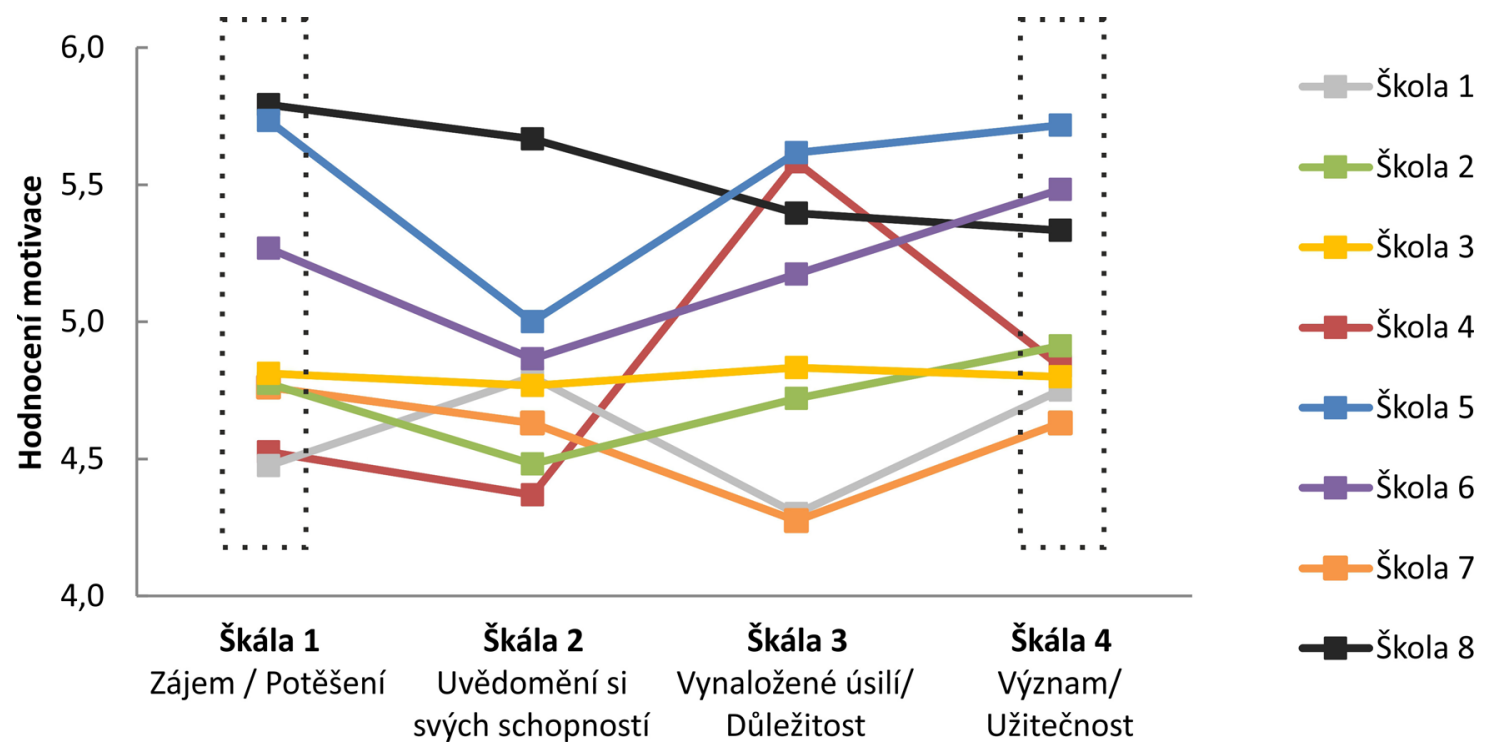

Obr. 3: Motivační orientace žáků - výstupní dotazník (Post) - vliv navštěvované školy (střední hodnoty)

$S D=0,99, M_{\text {škola } 6}=4,63, S D=1,00, M_{\text {škola }}=4,01, S D=1,26, M_{\text {škola } 8}=4,29$, $S D=1,00)$ (viz obr. 2).

Podobně lze vypozorovat také rozdíly ve výstupním měření u subškály „Zájem/potěšení“ (Post1) $\left(F(7,116)=2,424, p=0,024 ; M_{\text {škola1 }}=4,48, S D=0,85\right.$, $M_{\text {škola2 }}=4,77, S D=1,43, M_{\text {škola3 }}=4,81, S D=1,24, M_{\text {škola } 4}=4,53, S D=$ $=1,45, M_{\text {škola } 5}=5,73, S D=1,04, M_{\text {škola } 6}=5,27, S D=1,28, M_{\text {škola } 7}=4,76$, $\left.S D=1,28, M_{\text {škola8 }}=5,79, S D=0,99\right)$ a „Vynaložené úsilí/důležitost" (Post3) $\left(F(7,116)=3,871, p=0,001 ; M_{\text {škola1 }}=4,30, S D=0,79, M_{\text {škola2 }}=4,72, S D=1,21\right.$, $M_{\text {škola3 }}=4,83, S D=1,61, M_{\text {škola4 }}=5,58, S D=0,94, M_{\text {škola } 5}=5,62, S D=0,93$, $\left.M_{\text {škola } 6}=5,17, S D=1,05, M_{\text {škola7 }}=4,27, S D=0,95, M_{\text {škola8 }}=5,40, S D=1,13\right)$ (viz obr. 3, vyznačené rámečky). 
Komplexnější interpretace výsledků je v případě uvedeného faktoru (navštěvovaná škola) obtížnější, nebot jednotlivé školy se velmi liší a významný vliv na výsledky má nejen kvalita a koncepce úloh, či práce s MBL, ale roli hrají také atmosféra školy, konkrétní skupina žáků (třída), kvalita a osobnost učitele a další vlivy. Z výsledků (obr. 2 a 3 ) lze vysledovat, že ve vstupním dotazníku (položky Pre1 a Pre4) byli motivovanější žáci gymnázií více než odborných středních škol. To může být způsobeno také tím, že na obou středních odborných školách je výuka přirodních věd vedena $\mathrm{s}$ důrazem na naučení a zvládnutí fakti̊, zároveň je poměrně výrazně obohacena laboratorními cvičeními ve srovnání s gymnázii.

Žáci se tedy na další laboratorní cvičení „netěšili“ tak jako žáci sledovaných gymnázií. Dalším faktorem, který mohl přispět k danému výsledku, bylo, že v případě žáků gymnázií se jednalo často o žáky seminářů zaměřených na chemii, zatímco u žáků odborných středních škol se jednalo o běžné třídy. Dané úlohy se tak z hlediska motivace zdají být vhodnější pro gymnázia, nicméně může existovat řada přičin, které mohou ovlivnit výsledky i opačným směrem a nelze toto tvrzení považovat za jednoznačné. Statisticky významné rozdíly byly vysledovány také u škály „Zájem/potěšení“ (Post1). Za zajímavé lze považovat, že i přesto, že žáci jedné ze středních škol nebyli př́liš motivováni před realizací aktivity, po její realizaci (výstupní dotazník) naopak projevili nejvyšší motivaci. Cvičení, aktivity a zvolený jiný přístup k řešení úlohy tyto žáky zjevně zaujal nejvíce a jejich vnitřní motivace tak výrazně vzrostla (zhruba o 1,5b). Lze dodat, že úroveň motivace byla i u většiny ostatních skupin žáků poměrně vysoká. Významné rozdíly mezi jednotlivými skupinami byly také pozorovány ve škále „Vynaložené úsilí/důležitost“ (Post3). Tam opět žáci úlohy považovali za „důležitějšsi“ (a vynaložené úsilí bylo větší) v případě žáků odborné střední školy Škola 8 a také v př́ípadě žáků Školy 5 a Školy 6 . Na druhé straně škály se pohybovali žáci Školy 7 a Školy 1 . Výsledky lze patrně vysvětlit tím, že zatímco žáci z gymnázií byli z odborně zaměřených seminářů, ostatní žáci ze škol na druhé straně škály nikoliv. O žáky běžných tříd se jednalo i v případě Školy 8, ale v tomto prŕpadě se patrně projevil fakt, že jde o žáky odborné školy zaměřené na chemii, díky svému zaměření tedy aktivitám a jejich realizaci přikládali vyšší význam a aktivity je více bavily, a proto byli ochotni také vynaložit vyšší úsilí. Vzhledem k tomu, že statisticky významné rozdíly byly identifikovány u škál, které souvisí s vnitřní motivací žáků, výsledky taktéž naznačují, že dané školy navštěvují různě motivovaní žáci a při výběru té „správné“ školy hraje roli vnitřní motivace žáka. $\mathrm{V}$ obou posledně zmíněných případech jde vzhledem $\mathrm{k}$ vlivu dalších nehodnocených (a nehodnotitelných) faktorů pouze o spekulace, ale data na ně mohou ukazovat.

Data získaná z dotazníků byla poté zpracována shlukovou (klastrovou) analýzou. Nejprve byla provedena hierarchická shluková analýza dat ze vstupních a výstupních dotazníků (s využitím Wardovy metody (Ward, 1963), která ukázala, že žáci mohou být na základě svých odpovědí rozděleni do 5 různých shluků v př́padě vstupních dotazníků a do 4 různých shluků v případě výstupních dotazníků. Následná nehierarchická shluková analýza (K-průměry) určila středy jednotlivých shluků (obr. 4 a 5$)$.

Jak již bylo zmíněno, motivace žáků dosahovala nadprůměrných výsledků, a to téměř ve všech škálách (Pre1, Pre3, Pre4), průměrné motivační skóre vždy leželo nad hodnotou 3,5. Výjimkou je škála patřící „vnější motivaci“. Přesto, že shluků bylo identifikováno 5, je zřejmé, že shluky 4 a 5 a shluky 1 a 3 jsou z pohledu motivačních orientací velmi podobné, kromě položky náležející právě vnější orientaci. Shluky 4 a 5 sdružují (vnitřně) velmi motivované žáky a jejich hodnocení motivač- 


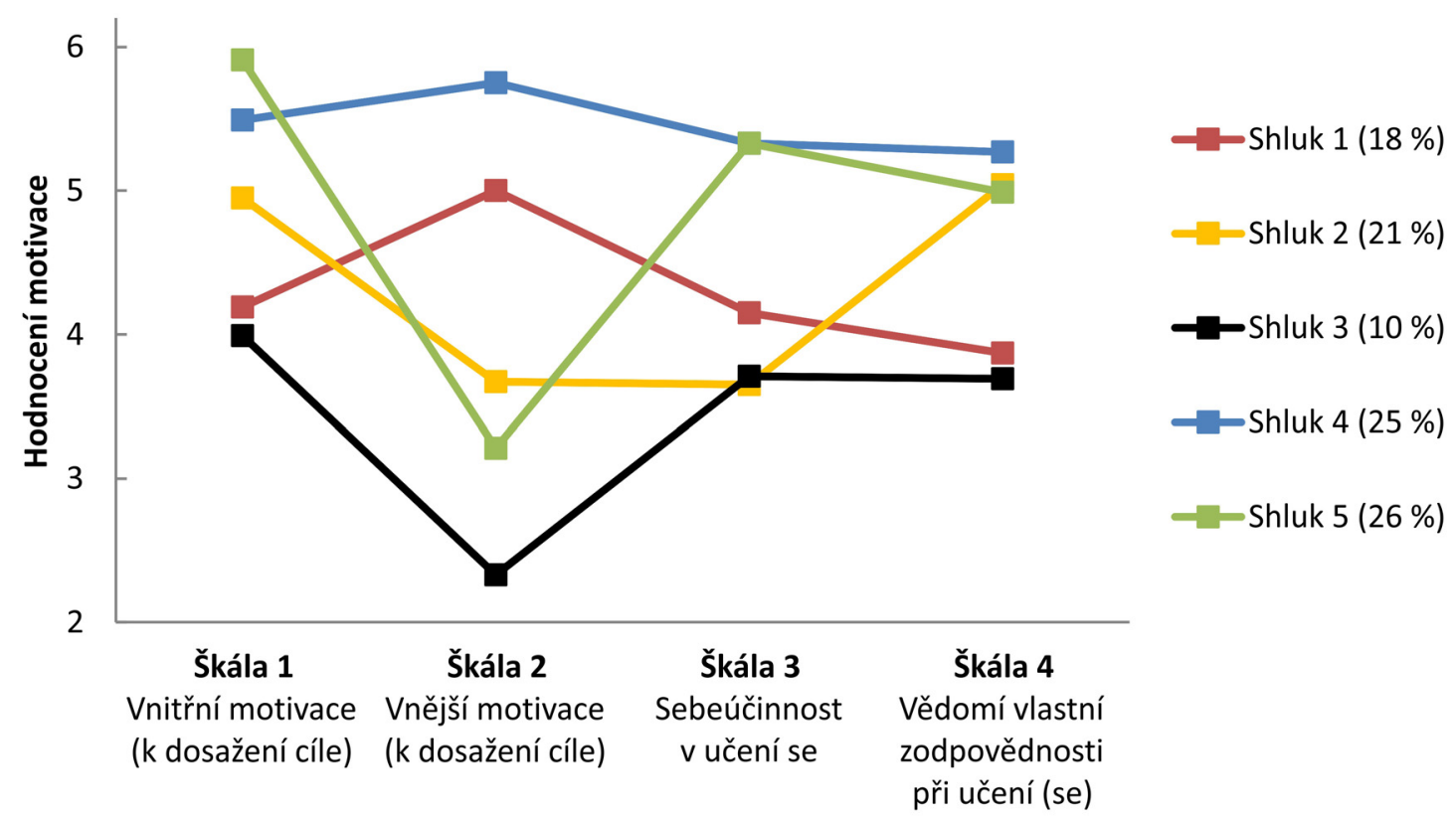

Obr. 4: Výsledky shlukové analýzy dat ze vstupních dotazníků (Pre; konečné středy shluků); procenta uvádějí zastoupení žáků v jednotlivých shlucích

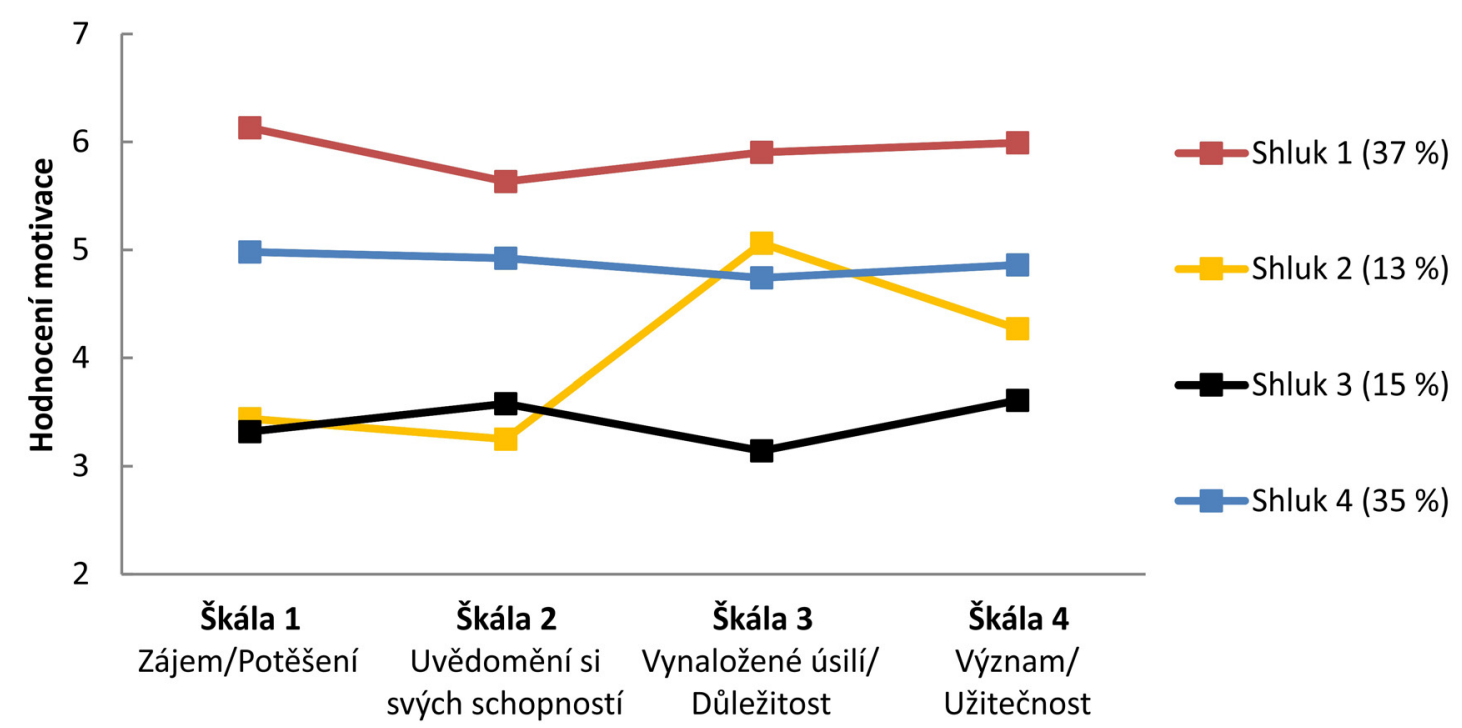

Obr. 5: Výsledky shlukové analýzy dat z výstupních dotazníků (Post; konečné středy shluků); procenta uvádějí zastoupení žáků v jednotlivých shlucích

ních orientací se povětšinou pohybuje nad hodnotou 5 . Těchto žáků je něco málo přes polovinu všech účastníků šetření. Z toho lze vyvodit, že většina žáků byla k realizaci aktivit poměrně dobře motivována, je ale žádoucí investovat do vnější motivace žáků. Průměrně motivovaných žáků bylo zhruba $21 \%$ a vyjádření jejich motivace $\mathrm{v}$ rámci dotazníků se pohybovalo okolo hodnoty 4 . Opět se u nich projevovala celkově nižší vnější motivace oproti ostatním položkám, je tedy zřejmé, že v tomto ohledu je stále co zlepšovat. Nejméně motivovaných (shluky 1 a 3 ) je $30 \%$, nicméně průměrné hodnocení těchto shluků se bliží spíše průměrné hodnotě 3,5 . Je opět zajímavé, že u shluků 1 a 3 se žáci příslušející jednotlivým skupinám liší opět pouze ve škále příslušející vnější motivaci. Patrně se projevuje vliv školy, který se ukázal být signifikantní. Celkově lze zopakovat, že většina žáků byla k realizaci aktivit motivována nadprůměrně a tito žáci přistupovali $\mathrm{k}$ praktiku s využitím školních experimentálních systémů pozitivně. 
Na obrázku 5 je prezentován výsledek shlukové analýzy pro případ výstupních dotazníků, který ukázal 4 shluky. Oproti vstupním dotazníkům jsou shluky ve všech subškálách rozloženy rovnoměrněji. Shluky 2 a 3 vykazují v průměrných hodnoceních značnou podobnost a liší se pouze $\mathrm{v}$ názoru na úsilí vynaložené $\mathrm{k}$ realizaci aktivit a důležitost. V tomto ohledu lze žáky účastnící se šetření rozdělit zhruba do tří skupin. U první z nich (37 \%) došlo ke zvýšení motivačních orientací (shluk 1), u druhé se motivační orientace změnily jen málo (shluk 4; $35 \%$ ) a u poslední skupiny (shluky 1 a 2) se motivační orientace snížily (celkem $28 \%$ žákü). Není asi překvapivé, že úlohy nezaujaly všechny žáky a že u určité skupiny došlo ke snížení motivačních orientací. Mohlo k ní dojít zejména v důsledku skutečnosti, že obtížnost úloh byla vyšší, i vzhledem k tomu, že byly zaměřeny mj. na fyzikálně-chemickou problematiku. Pozitivním sdělením pak může být, že zbytek žáků ( $72 \%$, tedy většina) si udržel či dokonce zvýšil svou motivaci. V uvedených proporcích (72\% vs $28 \%$ ) lze zhruba zhodnotit i jednotlivé položky výstupního dotazníku. Uvedenou většinu žáků práce na aktivitách s využitím školních měřicích systémů bavila a pokládali je za důležité, uvědomovali si také, že je třeba využít svých schopností k vyřešení úkolu. Zbytek žáků pak k úlohám přistupoval v rámci jejich zpracování spíše neutrálně. Celkově výsledky naznačují, že vytvořené aktivity mají z pohledu motivace žáků potenciál při využití ve výuce chemie prostřednictvím MBL, popř. prostřednictvím badatelsky orientované výuky, a že školní měřicí systémy mají ve výuce své místo z řady důvodů, a zájem a motivace žáků může být jedním z nich. Motivace pro práci s nimi je zřejmá a většina sledovaných žáků je pokládá taktéž za důležité.

I přes předpoklad technických preferencí chlapců se ukazuje, že pohlaví nemá velký vliv na motivační orientace a dívky pracují se školními měřicími systémy stejně „spokojeně“ jako chlapci. Naopak, celkem nepřekvapivě, velký vliv má škola, kde ale pro zhodnocení vlivu hraje roli řada dalších faktorů, které lze komplexně zhodnotit jen obtížně a může to být podkladem pro další studium.

Aspekt motivace je důležitým a často zmiňovaným prvkem výuky, ve spojení se školními měřicími systémy však dosud nebyl v ČR zkoumán, a proto není možné porovnat výsledky s jinými výzkumy. Můžeme však porovnat výsledky výzkumu mezi jednotlivými partnery. Nabízí se nám nejbližší partner, Slovensko, kde byly rovněž ověřovány chemické úlohy vytvořené v rámci COMBLAB projektu. Veškeré výsledky lze nalézt dostupné v publikaci M. Skoršepy (2015). Při podrobném porovnání lze zjistit, že výsledky slovenského partnera dosahují ve většině škál na Likertově škále vyššího skóre. Přitom oba partneři ověřovali stejný materiál, na podobných zařízeních (slovenské měřicí systémy byly navíc propojené se stolním počítačem, nikoli notebookem či tabletem jako v případě českého partnera) s téměř shodným metodickým postupem. Zjevně se do výsledků ale promítají další proměnné, jejichž přesná identifikace nebyla v původním záměru výzkumu zamýšlená.

Vnitřní motivací $\mathrm{v}$ přrirodovědném učení se v českém prostředí zabýval rovněž nedávný projekt ESTABLISH (Kekule et al., 2014), v jehož rámci bylo připraveno 18 poměrně rozsáhlých učebních jednotek reflektujících současná témata přírodovědného vzdělávání. Jako výzkumný nástroj byl použit dotazník, který mimo vlivu vnitřní motivace sledoval, jak žáci vnímají důležitost přírodních věd a technologií ve společnosti a zda mají jednotky vliv na rozhodování žáků věnovat se dále přírodním vědám. Ověřované jednotky byly žáky hodnoceny kladně (na škále zájem/potěšení dosahovalo skóre 69-83 \%) a jen o něco méně byla hodnocena užitečnost tématu. 


\section{ZÁVĚR}

V rámci projektu COMBLAB byl vypracován soubor šesti laboratorních úloh zaměřených na chemii. Tyto úlohy byly zpracovány v souladu s principy badatelsky orientované výuky (ř́izené bádání ve výuce) a s prvky sekvence POE. Jednalo se o aktivity s názvy: (1) Antacida (aneb zkoumání pH v žaludku po požití antacid); (2) Krásný skleník (sledování spekter různých chemických sloučenin a chlorofylu a absorpce světla těmito barvivy); (3) Červené nebo bílé? (zjištování kyselosti vína, $\mathrm{pH}$ titrace); (4) Stanovení chloridů (stanovení chloridů v pitné vodě prostřednictvím konduktometrické titrace), (5) Spektroskopie (kvalitativní a kvantitativní analýza barviv) a (6) Tichý zabiják (aneb plynová chromatografie směsi ethanolu a methanolu).

Žáci s využitím zmíněných úloh a s využitím školních měřicích systémů realizovali laboratorní cvičení o základní délce 90 minut. Vyhodnocení ukázalo, že vnitřní konzistence dat z dotazníkového šetření (vstupní a výstupní dotazník) realizovaného mezi 196 žáky gymnázií a středních odborných škol, je přijatelná a data mají ve většině použitých škál (vstupní dotazník: Vnitřní cílová orientace, Vnější cílová orientace, Sebeúčinnost v učení sebe sama a Vědomí vlastní zodpovědnosti při učení se; výstupní dotazník: Zájem/potěšení, Uvědomění si svých schopností, Vynaložené úsilí/důležitost a Význam/užitečnost) dostatečnou reliabilitu. Motivační orientace žáků jen málo závisela na sledovaných faktorech. V př́ípadě pohlaví se ukázalo, že dívky byly v položce „vynaložené úsilí/důležitost" motivovanější o něco více než chlapci. Aktivity byly v průměru žáky hodnoceny prakticky navzájem rovnocenně, snad jen úlohy vztahující se k medializovaným tématům a lidskému tělu, konkrétně účinnost antacid a plynová chromatografie (v kontextu methanolové aféry), byly z pohledu vnější cílové motivace (vstupní dotazník) hodnoceny lépe, žáci tedy před jejich zpracováním projevili vyšší očekávání. Nejdůležitějším faktorem, který v případě námi studovaného vzorku žáků ukázal statisticky významné rozdíly mezi odpověd’mi, byla navštěvovaná škola. V tomto ohledu jsou možnosti přesnější interpretace velmi omezené, nebot závisí na řadě dalších faktorů (klima školy/tř́idy, náročnost školy, osobnost učitele, způsob výuky na škole atd.). Lze ale říci, že z hlediska motivace jsou mezi školami rozdíly, tedy žáci jednotlivých škol nebudou k úlohám přistupovat stejně a nezískají ani stejné poznatky. Přirozeně jde o faktor významný a další výzkum v této oblasti je žádoucí.

Bylo zjištěno, že nejsou statisticky významné rozdíly v motivaci v rámci věkového rozpětí zkoumané skupiny žáků. V případě pohlaví se statisticky významný rozdíl objevil pouze v subškále "Vynaložené úsilí/důležitost".

Dále lze konstatovat, že většina žáků našeho vzorku byla před realizací aktivity dostatečně motivovaná, což ukázala nadprůměrná hodnocení jejich motivačních orientací. Výjimkou je subškála vnější motivační orientace, kde žáci, ve srovnání s ostatními škálami, většinou vykazovali nižší hodnocení. Dle vyhodnocení motivačních dotazníků po realizaci aktivity lze žáky rozdělit do čtyř skupin, z nichž u 37 \% došlo ke zvýšení motivace, žáci tedy laboratorní cvičení přijali kladně, u $35 \%$ se motivace změnily jen málo, žáci tedy přijali cvičení spíše neutrálně a 28 \% žáků vykazovalo snížení (13\%) či výraznější snížení (15\%) motivace, tedy cvičení je př́liš nenadchlo. Navzdory tomu odpovědi 85 \% žáků ukázaly, že žáci neváhali vynaložit k naplnění cílů cvičení vyšší úsilí a obsah cvičení považovali za důležitý. Lze tedy shrnout, že aktivity pozitivně ovlivnily motivaci (přesněji „Vnější cílovou orientaci“) většiny žáků.

Uvedené výsledky naznačují, že realizované aktivity jsou, z pohledu motivace žáků účastnících se výzkumu, zpracovány kvalitně a jsou vhodné pro výuku. Labo- 
ratorní cvičení se školními měřicími systémy žáky většinou bavila, a tak lze celkově říci, že jsou žáci nakloněni implementaci měřicích systémů do výuky, a ty tedy mají ve výuce své místo.

\section{PODĚKOVÁNí}

Tato práce byla podpořena projekty COMBLAB - 517587-LLP-1-2011-1-ES-COMENIUS-CMP uděleným v rámci programu COMENIUS (projekt EU) a PRVOUK P42. Za udělenou podporu těmto projektům děkujeme.

\section{LITERATURA}

Aksela, M. (2005). Supporting meaningful chemistry learning and higher-order thinking through computer-assisted inquiry: A design research approach. [Disertační práce]. Helsinki: University of Helsinki.

Atar, H. Y. (2002). Chemistry students' challenges in using MBL's in science laboratories. In Proceedings of association for the education of teachers in science. Charlotte: Association for the Education of Teachers in Science.

Barise, A. (1998). The effectiveness of case-based instruction vs. the lecture-discussion method in multicultural social work. [Disertační práce]. Montreal: McGill University.

Barton, R. (1997). How do computers affect graphical interpretation? School Science Review, 79(287), 55-60.

Bílek, M. (1992) Chemický experiment a mikropočítač. Mezinárodní seminář o vyučování chemii - sborník přednášek II (33-35). Hradec Králové: VŠP.

Bílek, M. (1993). Školní experiment a mikropočítač. MEDACTA 93 - sborník mezinárodního sympózia č. 5. Nitra: VŠPg.

Bílek, M. \& kol. (1997). Výuka chemie s počítačem. Hradec Králové: Gaudeamus, Hradec Králové.

Boone, H. N. J. \& Boone, D. A. (2012). Analyzing Likert data. Journal of Extension, $50(2)$.

Brasell, H. (1987). The effect of real-time laboratory graphing on learning graphic representations of distance and velocity. Journal of Research in Science Teaching, 24(4), $385-395$.

Campbell, M. M. (2001). Motivational strategies, learning strategies and the academic performance of African-American students in a college business environment:

A correlation study. Dissertation Abstracts International, 62(2-A), 432.

Cronbach, L. J. (1951). Coefficient alpha and the internal structure of tests.

Psychometrika, 16(3), 297-334.

Duda, J. L. (1992). Motivation in sport settings: A goal perspective approach. In

G. C. Roberts (Ed.), Motivation in sport and exercise (57-91). Champaign, IL (USA): Human Kinetics.

Hamne, P. \& Bernhard, J. (2001). Educating pre-service teachers using hands-on and microcomputer based labs as tools for concept substitution. In R. Pinto \& S. Surinach (Eds.), Physics teacher education beyond 2000 (663-666). Paris: Elsevier.

Higgins, E. T. (1997). Beyond pleasure and pain. American Psychologist, 52, 1280-1300. 
Hood, B. J. (1994). Research on computers in chemistry education: reflections and predictions March 29, 1993. Journal of Chemical Education, 71(3), 196-200.

Kekule, M., Žák, V. et al. (2014). Inquiry based science education and collecting evidence about its impact on students (Establish project approach). In

C. P. Constantinou, N. Papadouris \& A. Hadjigeorgiou (Eds.), E-Book Proceedings of the ESERA 2013 Conference: Science Education Research For Evidence-based Teaching and Coherence in Learning. Part 14 (co-ed. Couso, D., Louca, L.) (1-11). Nicosia, Cyprus: European Science Education Research Association.

Král, P., Kanderová, M. \& Kaščáková, A. et al. (2009). Viacrozmerné štatistické metódy so zameraním na riešenie problémov ekonomickej praxe. Banská Bystrica: Ekonomická fakulta UMB.

Lam, T. (1983). Tools of the trade: Microcomputer-based instrumentation: As easy as ADC. Hands On!, 6(2), 18-19.

Laws, P. W. (1991). Calculus-based physics without lectures. Physics Today, 44(12), $24-31$.

Lepper, M. R., Henderlong Corpus, J. \& Iyengar, S. (2005). Intrinsic and extrinsic motivational orientations in the classroom: Developmental trends and academic correlates. Journal of Educational Psychology, 97, 184-196.

Likert, R. (1932). A technique for the measurement of attitudes. Archives of Psychology, $22(140), 1-55$.

Linn, M. C. (1988). Curriculum reformation: Incorporating technology into science instruction. In Annual meeting of the American Educational Research Association. New Orleans.

Lustig, F., Lustigová, Z. \& Vlášek, P. (1992). ISES - př́ručka k soupravě Školní experimentální systém, Učební pomůcky PC-IN/OUT. Praha.

Markland, D. \& Hardy, L. (1997). On the factorial and construct validity of the Intrinsic Motivation Inventory: Conceptual and operational concerns. Research Quarterly for Exercise and Sport, 68(1), 20-32.

McAuley, E., Duncan, T. \& Tammen, V. V. (1989). Psychometric properties of the Intrinsic Motivation Inventory in a competitive sport setting: A confirmatory factor analysis. Research Quarterly for Exercise and Sport, 60, 48-58.

Mokros, J. R. \& Tinker, R. F. (1987). The impact of microcomputer-based labs on children's ability to interpret graphs. Journal of Research in Science Teaching, 24(4), $369-383$.

Monetti, D. M. (2002). A multiple regression analysis of self-regulated learning, epistemology and student achievement. Dissertation Abstracts International, 61(10-A), 3294 .

Nachmias, R. \& Linn, M. C. (1987). Evaluations of science laboratory data: The role of computer-presented information. Journal of Research in Science Teaching, 24(5), 491-506.

Nakhleh, M. B. (1994). A review of microcomputer-based labs: How have they affected science learning? Journal of Computers in Mathematics and Science Teaching, 13(4), $368-381$.

Niemi, H., Nevgi, A. \& Virtanen, P. I. (2003). Towards self-regulation in web-based learning. Journal of Educational Media, 28(1), 49-71. 
Pintrich, P. R. et al. (1991). A manual for the use of the Motivated Strategies for Learning Questionnaire (MSLQ). Michigan (US): Ann Arbor, National Centre for Research to Improve Postsecondary Teaching and Learning.

Plant, R. W. \& Ryan, R. M. (1985). Intrinsic motivation and the effects of self-consciousness, self-awareness, and ego-involvement: An investigation of internally controlling styles. Journal of Personality, 53(3), 435-449.

Rotgans, J. I. \& Schmidt, H. G. (2010). The Motivated Strategies for Learning Questionnaire: A measure for students' general motivational beliefs and learning strategies? The Asia-Pacific Education Researcher, 19(2), 357-381.

Russell, D. W., Lucas, K. B. \& McRobbie, C. J. (2003). The role of the microcomputer-based laboratory display in supporting the construction of new understandings in kinematics. Research in Science Education, 33(2), 217-243.

Ryan, R. M. (1982). Control and information in the intrapersonal sphere: An extension of cognitive evaluation theory. Journal of Personality and Social Psychology, 43(3), $450-461$.

Skoršepa, M. (2001). Konduktometrické titrácie s SM Systémom. In Zborník z 53. Zjazdu chemických spoločností (179-180). Banská Bystrica: FPV UMB.

Skoršepa, M. (2015). Počítačom podporované experimenty v prírodovednom vzdelávaní. Banská Bystrica: Belianum (Vydavate stvo UMB).

Skoršepa, M., \& Melicherčík, M. (2003). Vplyv koncentrácie reaktantov na priebeh chemických reakcií sledovate ných prostredníctvom merania zmien vodivosti (počítačom podporovaný chemický experiment). In Sborník z mezinárodní konference „Pregraduální př́iprava a postgraduální vzdělávání učiteli chemie" (330-334). Ostrava: OU.

Skoršepa, M., Stratilová Urválková, E., Šmejkal, P., Tortosa, M. M.

\& Urban-Woldron, H. (2014). Activities with sensors in laboratory of biology: Students' motivation and understanding the activities. In Nodzyńska, M., Cieśla, P. \& Kania, A. (Eds.), Experiments in teaching and learning natural sciences (25-33). Kraków: Pedagogická univerzita.

Skoršepa, M. \& Śmejkal, P. (2015). Psychometrické vlastnosti nástrojov na zistoovanie motivačnej orientácie žiakov v digitálnom prírodovednom laboratóriu. In Didaktika chemie a jeji kontexty (180-186). Brno: Masarykova univerzita.

Sneider, C. et al. (1986) Making sense out of data. Classroom Computer Learning, 6(7), $30,35-37$.

SPSS INC. (2009). PASW Statistics for Windows. Verze 18.0. Chicago: SPSS Inc. Stein, J. S. (1987). The computer as laboratory partner: Classroom experience gleaned from one year of microcomputer-based laboratory use. Journal of Educational Technology Systems, 15(3), 225-236.

Stratilová Urválková, E., Šmejkal, P., Skoršepa, M., Teplý, P. \& Tortosa, M. (2014). MBL Activities Using IBSE: Learning biology in context. In P. Cieśla \& A. Michniewska (Eds.), Teaching and learning science at all levels of education (131-134). Kraków:

Pedagogická univerzita.

Stratilová Urválková, E., Šmejkal, P., Teplý, P., Skoršepa, M., Tortosa, M., Urban-Woldron, H. (2014). New IBSE oriented activities for biology - design and evaluation. In M. Bílek (Ed.), Science and technology education for the 21st century, research and research oriented studies, Proceedings of the 9th IOSTE Symposium for Central and Eastern Europe (274-285). Hradec Králové: Gaudeamus. 
Svec, M. (1999). Improving graphing intrepretation skills and understanding of motion using microcomputer based laboratories. Electronic Journal of Science Education, 3(4).

Šmejkal, P., Stratilová Urválková, E. (2008) Př́istroje ve výuce chemie, realita nebo fikce? In Acta Facultatis Paedagogicae Universitatis Tyrnaviensis, Séria D: Vedy o výchove a vzdelávání, Supplementum 2 - Aktuálne vývojové trendy vo vyučovaní chémie (183-187). Trnava.

Šmejkal, P., Stratilová Urválková, E. (2012). Support for use of probeware in science for teachers and pupils. In DidSci (The 5th International Conference - Research in Didactics of the sciences). Krakow: Pedagogical University Krakow.

Thornton, R. K. (1986). Tools for Scientific Thinking: Microcomputer-Based Laboratories for the Naive Science Learner. Příspěvek ve sborníku konference National Educational Computing Konference, San Diego, Kalifornie.

Thornton, R. K. (1989). Using the microcomputer-based laboratory to improve student conceptual understanding in Physics. In Microcomputers in Physics Education. Proceedings of a Symposium. Adana, Turkey.

Thornton, R. K. \& Sokoloff, D. R. (1990). Learning motion concepts using real-time microcomputer-based laboratory tools. American Journal of Physics, 58(9), 858-867.

Tinker, R. (1984). Microcomputers in the lab: Techniques and applications. Cambridge: Technical Educational Research Center.

Tinker, R. (1985). How to Turn Your Computer Into a Science Lab. Classroom Computer Learning, 5(6), 26-29.

Tinker, R. (1996). Microcomputer-based labs: educational research and standards. Berlin: Springer-Verlag.

Tinker, R. (2000). A History of Probeware. Historický přehled publikovaný na stránkách Concord Consortium. Dostupné

z http://www.concord.org/sites/default/files/pdf/probeware_history.pdf

Urban-Woldron, H., Tortosa, M. \& Skoršepa, M. (2013). Implementing learning with sensors in science education: Students' motivational orientations toward using MBL. In C. P. Constantinou, N. Papadouris \& A. Hadjigeorgiou (Eds.), E-Book Proceedings of the ESERA 2013 Conference: Science Education Research For Evidence-based Teaching and Coherence in Learning (848-854). Strand 4. Nicosia, Cyprus: European Science Education Research Association.

Urválková, E., Šmejkal, P. \& Čtrnáctová, H. (2005). Laboratorní experimenty zaznamenávané přistrojem Infraline Graphic. Aktuální otázky výuky chemie $X V$ (396-401). Hradec Králové: Gaudeamus.

Ward, J. H. J. (1963). Hierarchical grouping to optimize an objective function. Journal of the American Statistical Association, 58(301), 236-244.

White, R. T. \& Gunstone, R. F. (1992). Probing Understanding. Great Britain: Falmer Press.

Whitehead, J. R. \& Corbin, C. B. (1991). Effects of fitness test type, teacher, and gender on exercise intrinsic motivation and physical self-worth. Journal of School Health, 61(1), $11-16$.

Wiser, M. (1987). The differentiation of heat and temperature: An evaluation of the effect of microcomputer teaching on students' misconceptions. Technická zpráva 1987-5. Educational Technology Center, Cambridge, Massachusetts. Dostupné z http://www.eric.ed.gov/PDFS/ED291596.pdf 
Wolters, C. A. (2004). Advancing achievement goal theory: Using goal structures and goal orientations to predict students' motivation, cognition, and achievement. Journal of Educational Psychology, 96(2), 236-250.

Woodard, F. E., Woodard, W. S. \& Reilley, C. N. (1981). Microprocessor-based laboratory data acquisition systems. Analytical Chemistry. 53(11), 1251A-1252A, 1254A, $1256 \mathrm{~A}, 1258 \mathrm{~A}, 1261 \mathrm{~A}-62 \mathrm{~A}, 1264 \mathrm{~A}, 1266 \mathrm{~A}$.

Petr ŠmeJKal, Petr.Smejkal@natur.cuni.cz

Eva Stratilová URvÁlKová, urvalkov@natur.cuni.cz

PAVEL TEPLÝ, Pavel.teply@natur.cuni.cz

Univerzita Karlova v Praze, Př́rodovědecká fakulta

Katedra učitelství a didaktiky chemie Albertov 3, 12843 Praha 2, Česká republika

MAREK SKORŠEPA, Marek.Skorsepa@umb.sk

Univerzita Mateja Bela, Fakulta prírodných vied

Katedra chémie Tajovského 40, 97401 Banská Bystrica, Česká republika 